University of Nebraska - Lincoln

DigitalCommons@University of Nebraska - Lincoln

Faculty Publications from the Harold W. Manter Laboratory of Parasitology

8-1951

\title{
Studies on the Helminth Fauna of Alaska. VII. On Some Helminths from Arctic Marmots with the Description of Catenotaenia reggiae n. sp. (Cestoda: Anoplocephalidae)
}

Robert L. Rausch

Arctic Health Research Center, rausch@u.washington.edu

Follow this and additional works at: https://digitalcommons.unl.edu/parasitologyfacpubs

Part of the Parasitology Commons

Rausch, Robert L., "Studies on the Helminth Fauna of Alaska. VII. On Some Helminths from Arctic Marmots with the Description of Catenotaenia reggiae n. sp. (Cestoda: Anoplocephalidae)" (1951). Faculty Publications from the Harold W. Manter Laboratory of Parasitology. 562.

https://digitalcommons.unl.edu/parasitologyfacpubs/562

This Article is brought to you for free and open access by the Parasitology, Harold W. Manter Laboratory of at DigitalCommons@University of Nebraska - Lincoln. It has been accepted for inclusion in Faculty Publications from the Harold W. Manter Laboratory of Parasitology by an authorized administrator of DigitalCommons@University of Nebraska - Lincoln. 


\section{STUDIES ON THE HELMINTH FAUNA OF ALASKA. VII-ON SOME HELMINTHS FROM ARCTIC MARMOTS WITH THE DESCRIPTION OF CATENOT AENIA REGGIAE N. SP. (CESTODA: ANOPLOCEPHALIDAE)}

\section{ROBERT RAUSCH ${ }^{1}$}

Among Alaskan mammals examined for helminthic parasites during 1950 was a series of marmots, Marmota caligata broweri Hall and Gilmore, 1934, from the Brooks Range, Arctic Alaska. The animals were collected a few miles south of Tolugak Lake (lat. $68^{\circ} 24^{\prime} \mathrm{N}$., long. $151^{\circ} 26^{\prime} \mathrm{W}$.), and from the vicinity of Kanayut Lake, about 15 miles northeast of Tolugak Lake. This distinctive marmot has been hitherto represented in collections only by the three specimens comprising the type material. In addition to greatly extending the known range of this form, the collection of these specimens also contributes the first information on Brooks Range marmots (Rausch, 1950).

Three species of helminths occurred frequently in the twenty-odd animals examined. They were Ascaris laevis Leidy, 1856, Diandrya composita Darrah, 1930, and an undescribed species of Catenotaenia von Janicki, 1904. Tiner (1951) has recently redescribed $A$. laevis, partially on the basis of Alaskan material. The writer has recovered this ascarid also from ground squirrels, Citellus parryi barrowensis (Merriam), from Umiat, which is located on the Colville River at the north edge of the Arctic Plateau, and from Tolugak Lake. It is uncommon in this host, however, and is therefore considered essentially a parasite of marmots. Cestodes tentatively determined as $D$. composita have been reported from Marmota c. caligata (Eschscholtz) in Alaska by Philip (1938). Philip also reported Ascaris tarbagan Shul'ts, 1931 from Marmota monax ochracea Swarth, collected in central Alaska. A more complete coverage of the parasitic helminths of Alaskan sciurids will be published when adequate data have been collected.

According to a review of the literature, and the Host Catalogue of the Zoological Division, Bureau of Animal Industry, no species of Catenotaenia has been recorded from marmots, although two species have been recorded from other sciurid hosts. The Brooks Range material is readily differentiated from previously-described species, and is described herewith as new.

\section{Catenotaenia reggiae n. sp.}

(Figs. 1-4)

Diagnosis: Anoplocephalidae. Maximum strobila length $360 \mathrm{~mm}$; greatest width, attained in gravid segments, $3 \mathrm{~mm}$. Complete strobila contains about 200 segments. Strongly serrated margins seen in anterior portion of strobila become gradually less evident and disappear toward the posterior end, where the gravid segments become sub-elliptical. Mature segments in contracted material measure about $1 \mathrm{~mm}$. long by $2 \mathrm{~mm}$. wide; in well relaxed strobilae, they measure up to $5 \mathrm{~mm}$. long by $1 \mathrm{~mm}$. wide. Scolex from 360 to $490 \mu$ in diameter; not distinct from unsegmented neck of equal width. Rostellum and apical sucker absent. Suckers from 144 to $220 \mu$ in diameter. Excretory canals of typical formation; ventral canal $32 \mu$ in diameter, and dorsal canal $8 \mu$ in diameter. Genital pores irregularly alternate, situated in anterior third of segment;

Received for publication, January 27, 1951.

1 Parasitologist, Arctic Health Research Center, U. S. Public Health Service, Fed. Security Agency, Anchorage, Alaska. 
position of genital pore relatively variable according to state of contraction of strobila. Cirrus sac claviform to pyriform, from 324 to $490 \mu$ long by 144 to $194 \mu$ wide in pre-gravid segments. Cirrus sac may or may not extend dorsally past the ventral excretory canal. Cirrus aspinose. Vas deferens somewhat coiled. Internal and external seminal vesicles absent. Testes, about 300 in number, ${ }^{2}$ situated in two lateral fields posterior to ovary; lateral fields not joined by band of testes at posterior end of segment. Vagina posterior to cirrus sac; course of vagina perpendicular to margin of segment in contracted material and directed postero-medially in relaxed segments. Vagina is uncoiled tube, abundantly supplied with surrounding glandular cells. Enlargement of variable size near medial end of vagina serves as seminal receptacle. Muchbranched vitelline gland poral, situated just posterior to proximal end of cirrus sac. Ovary highly branched and aporal, extending in well-relaxed material posteriad beyond anterior limits of vitelline gland. Uterine stem evident early in strobila. Form of gravid uterus typical for genus, with 30 to 40 lateral branches, often secondarily divided, on each side. Eggs spherical, from 17 to $28 \mu$ in diameter.

Host: Marmota caligata broweri Hall and Gilmore.

Type Locality: Tolugak Lake, Arctic Alaska.

Habitat: Small intestine.

Type: A whole mount containing a complete strobila has been deposited in the Helminthological Collection of the U. S. National Museum, slide no. 47535.

\section{DISCUSSION}

There are at least 8 apparently valid species, all parasitic in rodents, previously assigned to the genus Catenotaenia, viz., C. capensis Ortlepp, 1940, C. dendritica (Goeze, 1782), C. geosciuri Ortlepp, 1938, C. linsdalei McIntosh, 1941, C. lobata Baer, 1925, C. oranensis Joyeux and Foley, 1930, C. pusilla (Goeze, 1782), and $C$. rhombomidis Shul'ts and Landa, 1935. Of these, the description for C. rhombomidis is not available, and the species is not considered further here.

Catenotaenia reggiae is differentiated by the large size, strongly developed strobila, and cirrus sac length. On the basis of excretory system (determined from whole mounts only), which is net-like in C. lobata and $C$. capensis, C. reggiae falls into the group with those containing simple excretory canals, viz., $C$. pusilla, $C$. dentritica, $C$. oranensis, $C$. linsdalei, and $C$. geosciuri. It is separable from all but possibly $C$. capensis on the basis of testes number. $C$. reggiae is characterized also by form of gravid uterus (Fig. 3), which differs from any of the others with which it has other characteristics in common. It is perhaps most nearly similar to $C$. dendritica, but from this it can be separated by the failure of the testicular fields to unite (in C.reggiae) at the posterior end of the segment, by the great difference in cirrus sac size, and by the character of the gravid uterus.

In various anoplocephaline genera, including Catenotaenia, the lack of constant morphological characters (e.g., rostellar hooks) makes it necessary to pay particular attention to variation when specific differentiation is attempted. In Catenotaenia it would seem particularly advisable to take into consideration the state of strobilar contraction, since the relative positions of organs are often greatly influenced by this. Any lot of material consisting solely of strobilae either uniformly contracted or relaxed could convey an impression which might lead to an altogether erroneous conclusion in regard to specific characterization. Joyeux and Baer (1945) have remarked on the morphological variation seen in $C$. pusilla. It appears that gravid segments in some cases may show specific features more readily recognized than those seen in mature segments alone.

Possible variation related to host occurrence has been considered, since other

${ }^{2}$ Testes so numerous that an accurate count is not possible. 
species of the genus have been recovered from sciurid hosts, and host-specificity does not appear to be well developed. From North America only $C$. dentritica (erroneously reported by Rausch and Tiner (1948) as $C$. pusilla ${ }^{3}$ ) and C. linsdale $i$ have been reported. Of these, only the former so far has been reported from sciurids. Although some of the material available for study is in poor state of preservation, all seems referable to $C$. dendritica. The writer has collected this species from Sciurus niger rufiventer Geoffroy and Glaucomys sabrinus macrotis Mearns in the United States, and from Clethrionomys rutilus dawsoni (Merriam) from Alaska. No differences have been observed in this material which might be attributed to modification by host occurrence. It is concluded that the morphological peculiarities exhibited by C. reggiae are clearly specific in nature.

\section{REFERENCES}

Joyeux, Ch. ANd Baer, J. G. 1945 Morphologie, évolution et position systématique de Catenotaenia pusilla (Goeze, 1782), cestode parasite de Rongeurs. Rev. Suisse Zool. 52: 13-51.

PhILIP, C. B. 1938 A parasitological reconnaissance in Alaska with particular reference to varying hares. II. Parasitological data. J. Parasit. 24: 483-488.

Rausch, R. AND TINER, J. D. 1948 Studies on the parasitic helminths of the North Central States. I. Helminths of Sciuridae. Amer. Midl. Nat. 39: 728-747.

1950 Notes on the distribution of some arctic mammals. J. Mammal. 31: 464-466.

TINER, J. D. 1951 The morphology of Ascaris laevis Leidy 1856, and a note on ascarids in rodents. Proc. Helm. Soc. Wash. (In press.)

${ }^{3}$ The probable error in this identification was called to the writer's attention by Dr. J. G. Baer, who pointed out the prevalence of $C$. dendritica in Nearctic sciurids.

\section{Explanation of Plate}

Catenotaenia reggiae n. sp. Figs. 1,2, and 3 were drawn with the aid of a projector. The scale has a value of $250 \mu$ in figs. 1 and $4 ; 500 \mu$ in fig. $2 ; 1 \mathrm{~mm}$. in fig. 3 .

FIg. 1. Scolex.

FIG. 2. Mature segment, from well-relaxed strobila.

FIG. 3. Gravid segment.

FIG. 4. Semi-diagrammatic drawing of terminal region of genital ducts. 
Rausch in Journal of Parasitology (August 1951) v. 37, no. 4.

Copyright 1951, American Society of Parasitologists. Used by permission.

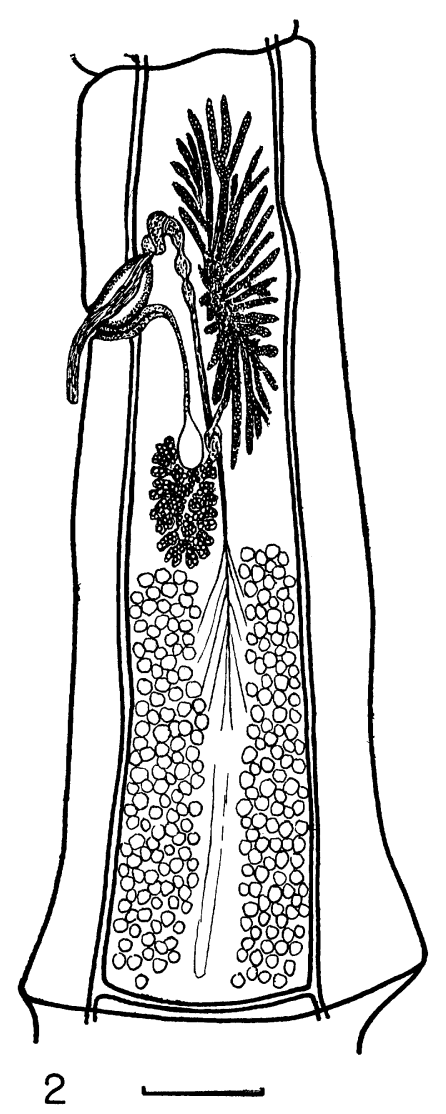

\section{Plate I}
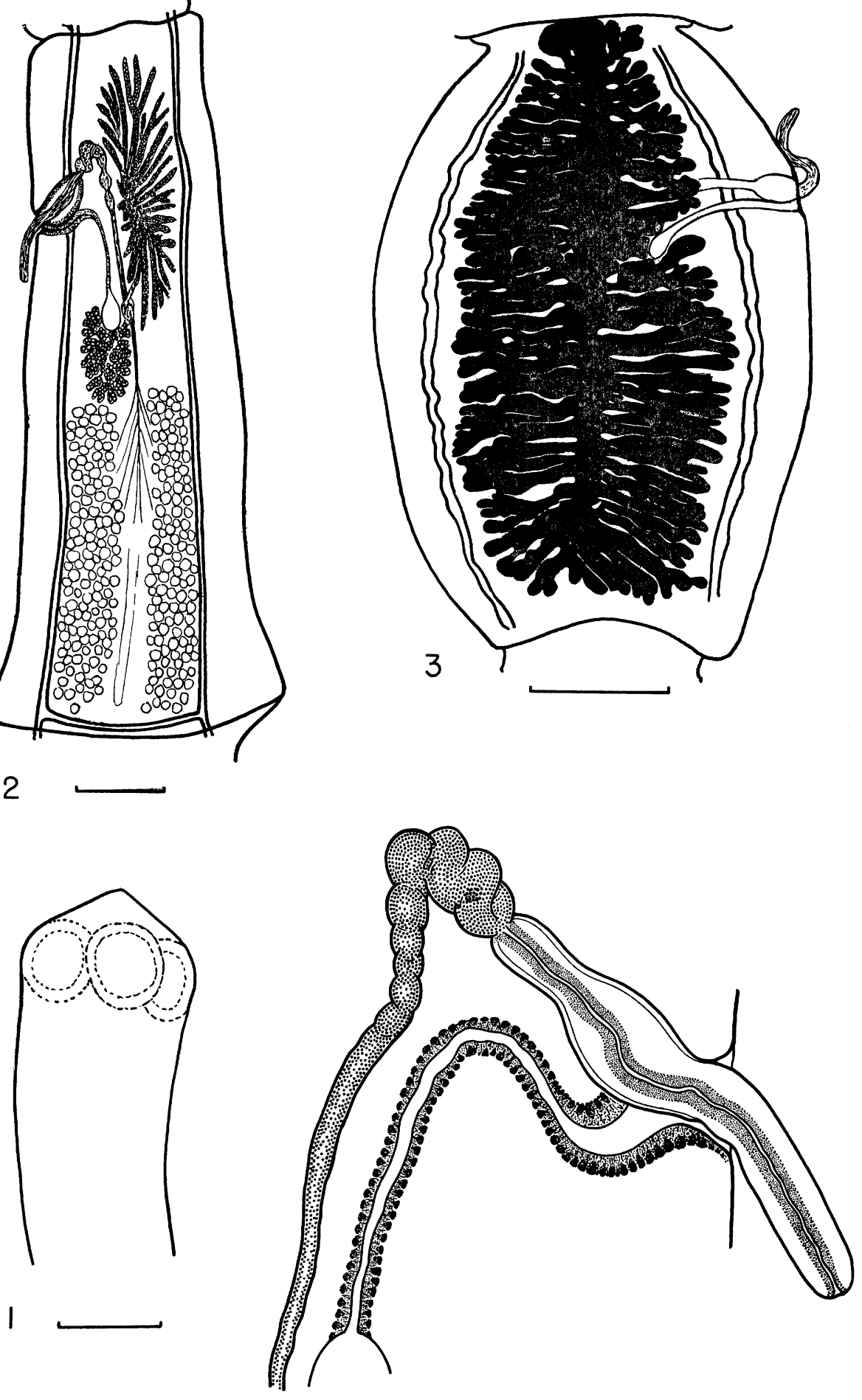

4 